\title{
Effects of pretreatments and storage temperature on the quality of lotus leaves
}

\author{
Jeong-Sil Choi ${ }^{1}$, Moon-Hee Kong ${ }^{2}$, Soo-Hwan Yeo ${ }^{1}$, Han-Seok Choi ${ }^{1}$, Seok-Tae Jeong ${ }^{1 *}$ \\ ${ }^{1}$ Fermented Food Science Division, National Institute of Agricultural Science, Wanju 55365, Korea \\ ${ }^{2}$ CJ Global Solution Center, Suwon 16495, Korea
}

\section{연잎의 품질특성에 미치는 전처리 방법과 저장온도의 영향}

\author{
최정실 ${ }^{1} \cdot$ 공문희 $^{2} \cdot$ 여수환 $^{1} \cdot$ 최한석 $^{1} \cdot$ 정석 태 $^{1 *}$ \\ ${ }^{1}$ 국립농업과학원 발효식품과, ${ }^{2} \mathrm{CJ}$ 제일제당 소재연구소 글로벌솔루션센터
}

\begin{abstract}
This study aimed to investigate the effects of pretreatments blanching, roasting, drying, and storage temperatures $\left(25^{\circ} \mathrm{C}, 4^{\circ} \mathrm{C}\right.$ and $\left.-10^{\circ} \mathrm{C}\right)$ on their quality of lotus leaves. As a result, the lotus leaves retained a good appearance when stored at $25^{\circ} \mathrm{C}$ for 5 days, $4^{\circ} \mathrm{C}$ for 30 days, and $-10^{\circ} \mathrm{C}$ for 90 days, regardless of the pretreatment used. At the same storage temperatures, $\mathrm{pH}$, soluble solids, total acid content, polyphenols, and microorganisms were significantly different among the pretreatments $(\mathbf{p}<\mathbf{0 . 0 5})$. Soluble solids, $\mathrm{pH}$, and total acid contents were not significantly different for the same pretreatments at different storage temperatures. However, the polyphenol, oxalic acid, and tartaric acid contents of lotus leaves were significantly different after drying and blanching treatments. In particular, it was shown that polyphenol content of the lotus leaf was affected by both pretreatment and storage temperature. In conclusion, the lotus leaves appeared in good condition until 5 days at $25^{\circ} \mathrm{C}, 30$ days at $4^{\circ} \mathrm{C}$, and 90 days at $-10^{\circ} \mathrm{C}$, regardless of the pretreatment while influenced by storage temperature.
\end{abstract}

Key words : Lotus leaf, pretreatment, storage, properties

\section{서 론}

연은 수련과 다년생 수초로 주로 연못에서 자라고 논밭 에서 재배되며 인도, 중국, 일본, 한국, 및 북호주 등에 널리 분포되어 있다. 현재 100 여 ha이상 재배되고 있는 연은 불교 에서는 신성한 식물로 여겨왔으며 그 꽃은 관상용이나 차의 재료로 쓰이고 잎과 뿌리는 주로 식용으로 이용해 왔다(1). 특히 동북아시아권인 중국에서는 연을 불로식(不老食)으로 취급하여 약재로 이용해 왔고 한국에서도 예로부터 연잎을 비롯한 연근, 연꽃, 연심 및 연자육 등을 식용 또는 약용으로 다른 약재와 혼용하여 열, 설사, 어지럼증, 위장 장애 등을

*Corresponding author. E-mail : jst@korea.kr

Phone : 82-63-238-3615, Fax : 82-63-238-3843

Received 1 December 2015; Revised 1 February 2016; Accepted 2 March 2016.

Copyright (c) The Korean Society of Food Preservation. All rights reserved.
치료하기 위한 용도로 사용해 왔다(2-4). 또한, 연근과 연잎 에는 alkaloid 성분, 비타민 및 flavonoides 등 다양한 생리활 성 성분을 함유하고 있어(5) 항산화(6), 지방 산화 억제(7,8), 지방축적 억제 효과 $(9,10)$ 및 항균효과(11) 등의 기능성에 대한 연구가 다수 이루어지고 있는 것으로 보고되었다. 기 능성 식품인 연잎으로 만든 제품으로는 연엽주, 연잎차 $(12,13)$ 등이 있으며 연잎밥을 비롯한 연잎을 이용한 다양한 조리방법 등이 개발되고 있다(14-17). 그러나 다양한 용도 로 쓰이고 기능성 성분을 지닌 연잎은 대부분 생체 형태로 소비되고 있는데, 생산시기가 6월에서 9월경으로 한정되어 있어서 연잎을 연중 이용하기 위해서는 생잎으로 보관하는 방법 또는 건조 등의 처리를 하여 장기간 보관할 수 있는 기술이 요구된다. 또한, 신선농산물은 수확 후에도 호흡, 증산작용과 같은 생리활동을 계속함에 따라 저장이나 유통 중에 품질을 저하시키는 원인이 되므로(18), 생산시기에 채취한 연잎을 향기나 기능성 성분의 손실 없이 저장성을 높이는 전처리 기술이 요구된다. 이에 신선농산물의 저장 
성을 높이는 전처리 기술로 덖음, 데치기, 건조 등이 사용된 다. 덖음은 덖으면서 탈수 및 건조하는 방법으로 차 제조시 생잎 특유의 풋내, 쓴맛, 떫은 맛과 같은 바람직하지 않은 향미를 감소시키고 가열에 의해 새로운 향미를 생성시켜 기호성을 증진시키는데 이용되며(19) 곡물이나 채소를 저 장하기 전에 짧은 시간 고온 가열하여 품질 저하에 관련된 효소를 불활성화함으로써 저장성을 높이는 데치기가 있다 (20). 또한, 건조는 수분을 제거하는 조작으로 미생물이나 효소에 의한 변질을 방지함으로써 저장성을 향상시키는 기술로 방법은 다양하나 열풍건조가 주를 이룬다(21).

본 연구에서는 연잎의 연중 활용성 증대를 위해 연잎의 저장기간을 늘리기 위한 다양한 전처리 방법과 저장온도에 따른 저장 한계기를 설정하여, 효율적인 이용방안을 제시 하고자 한다.

\section{재료 및 방법}

\section{실험재료 및 연잎의 전처리}

본 실험에 사용한 연잎은 백련잎(Nelumbo nucifera)으로, 경기도 시흥의 관곡지에서 8 월 중순에 수확한 것을 사용하 였다. 연잎을 1 2 cm로 세절하여 각각 데치기, 덖음, 건조 처리를 하여 지퍼백 $(\mathrm{PE} 0.1 \mathrm{~mm})$ 에 넣어 실온 $25^{\circ} \mathrm{C}$, 냉장 $4^{\circ} \mathrm{C}$, 및 냉동 $-10^{\circ} \mathrm{C}$ 에 보관하면서 분석시료로 사용하였다. 이때, 처리를 하지 않은 생잎을 대조구로 하였다.

생잎처리는 연잎을 4 등분 후 그대로 저장하였으며, 데치 기는 세절한 연잎을 끓는 물에서 20-30초간 처리 후 건져내 어 상온에서 냉각하였다. 덖음 처리는 약 $130 ~ 150^{\circ} \mathrm{C}$ 에서 $2 \sim 3$ 분간 처리 후 상온에서 냉각하였다. 건조처리는 $40^{\circ} \mathrm{C}$ 의 건조기에서 48 시간 건조 후 방냉하였다.

\section{분석방법}

분석시료 준비

Fig. 1에서 나타나는 바와 같이 육안으로 보았을 때 부패 가 진행되기 전에 저장 온도별 $\left(4^{\circ} \mathrm{C}, 25^{\circ} \mathrm{C}\right.$, 및 $\left.-10^{\circ} \mathrm{C}\right)$ 로 외관 상 이상이 없는 시점의 연잎을 선정하여 $\left(4^{\circ} \mathrm{C} ; 30\right.$ 일, $25^{\circ} \mathrm{C}$; 5 일, 및 $-10^{\circ} \mathrm{C}$; 90 일) $13 \%$ alcohol을 $(2 \mathrm{~g} / 40 \mathrm{~mL})$ 넣고 5,000 $\mathrm{rpm}$ 에서 5 분 동안 균질기(WiseTis, Model HG-15D, Daihan Scientific Co., Wonju, Korea)를 이용하여 균질화하고 30분 간 방치한 후 $4{ }^{\circ} \mathrm{C}$ 에서 $3,500 \mathrm{rpm}$ 으로 15 분간 원심분리 (Hitachi CR22G III, Hitachi Co., Ltd., Tokyo, Japan)하여 상등액을 분석용 연잎 추출액으로 사용하였다.

\section{$\mathrm{pH}$, 총산 및 가용성 고형분 분석}

$\mathrm{pH}$ 는 $\mathrm{pH}$ meter(Beckman, Model 115PD, Istek Co., Seoul, Korea)를 이용하여 측정하였고, 총산은 연잎추출액 $10 \mathrm{~mL}$ 를 삼각플라스크에 넣고 $0.1 \mathrm{~N} \mathrm{NaOH}$ 로 $\mathrm{pH}$ 8.2가 될 때까지
적정하여 그 값을 호박산(succinic acid)으로 환산하여 나타 내었다. 가용성 고형분은 디지털 굴절계(PR-201, Atago Co., Tokyo, Japan)를 사용하여 측정하고 ${ }^{\circ} \mathrm{Brix}$ 로 나타내었다.

\section{총폴리페놀 및 유기산}

총폴리페놀 함량은 Jung 등(22)의 방법에 따라 연잎 추출 액 $1 \mathrm{~mL}$ 에 $0.2 \mathrm{M}$ sodium acetate(pH 1.0) $9 \mathrm{~mL}$ 를 넣어 $280 \mathrm{~nm}$ 에서 UV-visible spectrophotometer(JP/U-2000 spectrophotometer, Hitachi Co., Ltd., Tokyo, Japan)로 측정하여 gallic acid 표준 용액 검량선으로 환산하여 나타내었다. 유기산 분석은 연 잎 추출액 시료를 증류수로 5 배 희석하여 고분자물질과 색소를 제거하기 위하여 Sep-pak(Oasis HLB $60 \mu \mathrm{m}$ Catridge, Waters Co., Ltd., Miliford, MA, USA) 및 membrane filter(nylon, $0.22 \mu \mathrm{m}$, Merck Millipore Ltd., Damstadt, Germany)로 여과하여 HPLC(LC-20A, Shimadzu Co., Kyoto, Japan)를 이용하였으며 post column방법을 사용하여 분석하였다. 분석용 column은 KC-811 $(8.0 \mathrm{~mm} \times 300 \mathrm{~mm}$, Showa Denko Co., Tokyo, Japan)을 사용하였으며, 이동상은 $3 \mathrm{mM}$ perchloric acid로 유속 $0.8 \mathrm{~mL} / \mathrm{min}$, column oven 온도 $63^{\circ} \mathrm{C}$, injection volume $10 \mu \mathrm{L}$ 로 하였다. 분리물은 반응용액 ( $0.2 \mathrm{mM}$ bromothymol blue, $15 \mathrm{mM} \mathrm{Na} 2 \mathrm{HPO}_{4}, 2 \mathrm{mM} \mathrm{NaOH}$ ) 과 반응한 후 UV $440 \mathrm{~nm}$ 에서 검출하였다. 이때 반응용액의 flow rate는 $1.0 \mathrm{~mL} / \mathrm{min}$, 반응온도는 $30^{\circ} \mathrm{C}$ 로 하였다.

\section{미생물 분석}

미생물 검사는 연잎 추출액 시료액 $1 \mathrm{~mL}$ 를 취하여 9 $\mathrm{mL}$ 의 $0.85 \%$ 멸균생리식염수로 단계 희석하였다. 시험용액 $1 \mathrm{~mL}$ 와 각 단계 희석액 $1 \mathrm{~mL}$ 를 각각 일반세균용, 효모 \& 곰팡이용 3M petrifilm(PetrifilmTM plate, 3M Co., St. $\mathrm{Paul}, \mathrm{MN}, \mathrm{USA}$ )에 접종하고 일반세균은 $36^{\circ} \mathrm{C}$ incubator에 서 3 일간, 효모와 곰팡이는 $25^{\circ} \mathrm{C}$ incubator에서 5 일간 배양 하였다. Colony forming unit $(\mathrm{CFU} / \mathrm{mL})$ 으로 표시하였다.

\section{통계분석}

모든 데이터는 3 회 반복 측정하였으며, 평균표준편차 로 표시하였다. 통계분석은 SPSS 프로그램 12.0 버전을 사 용하여 분산분석(ANOVA)과 다변량분산분석(MANOVA) 를 실시하였고, 유의적인 차이가 있는 경우 $a=0.05$ 수준에 서 사후검정 중의 하나인 Duncan의 다중범위 검정을 실시 하여 처리구간 유의성을 검정하였다.

\section{결과 및 고찰}

\section{외관적 특성}

연구 결과 외관상으로 보았을 때, 상온 $\left(25^{\circ} \mathrm{C}\right)$ 에서 보관할 경우 5일까지 모든 처리구의 저장 상태가 양호하였다. 저장 10 일째에는 건조 처리한 연잎을 제외하고 모든 처리구에서 
갈변현상이나 곰팡이를 발견할 수 있었다. 갈변현상은 연 잎에 있는 폴리페놀 물질이 폴리페놀산화효소에 의해 산화 됨으로 갈색을 띠는 것으로 사료된다 $(23)$. 냉장 $\left(4^{\circ} \mathrm{C}\right)$ 에서 보관할 경우 30 일까지 생연잎에서 약간의 갈변을 제외하고 모든 처리구에서 양호하였다. 저장 60 일째는 건조 처리한
연잎을 제외하고는 모든 처리구에서 곰팡이가 생겼다. 냉 동 $\left(-10^{\circ} \mathrm{C}\right)$ 에서 보관할 경우 전처리 방법에 차이 없이 90 일 까지 양호하였다. 이를 통해 보았을 때 외관상으로는 상온 $\left(25^{\circ} \mathrm{C}\right)$ 이나 냉장 $\left(4^{\circ} \mathrm{C}\right)$ 에서 보관할 경우 건조한 연잎이 좋았 고 냉동 $\left(-10^{\circ} \mathrm{C}\right)$ 에서 보관할 경우 연잎은 전처리 방법에는

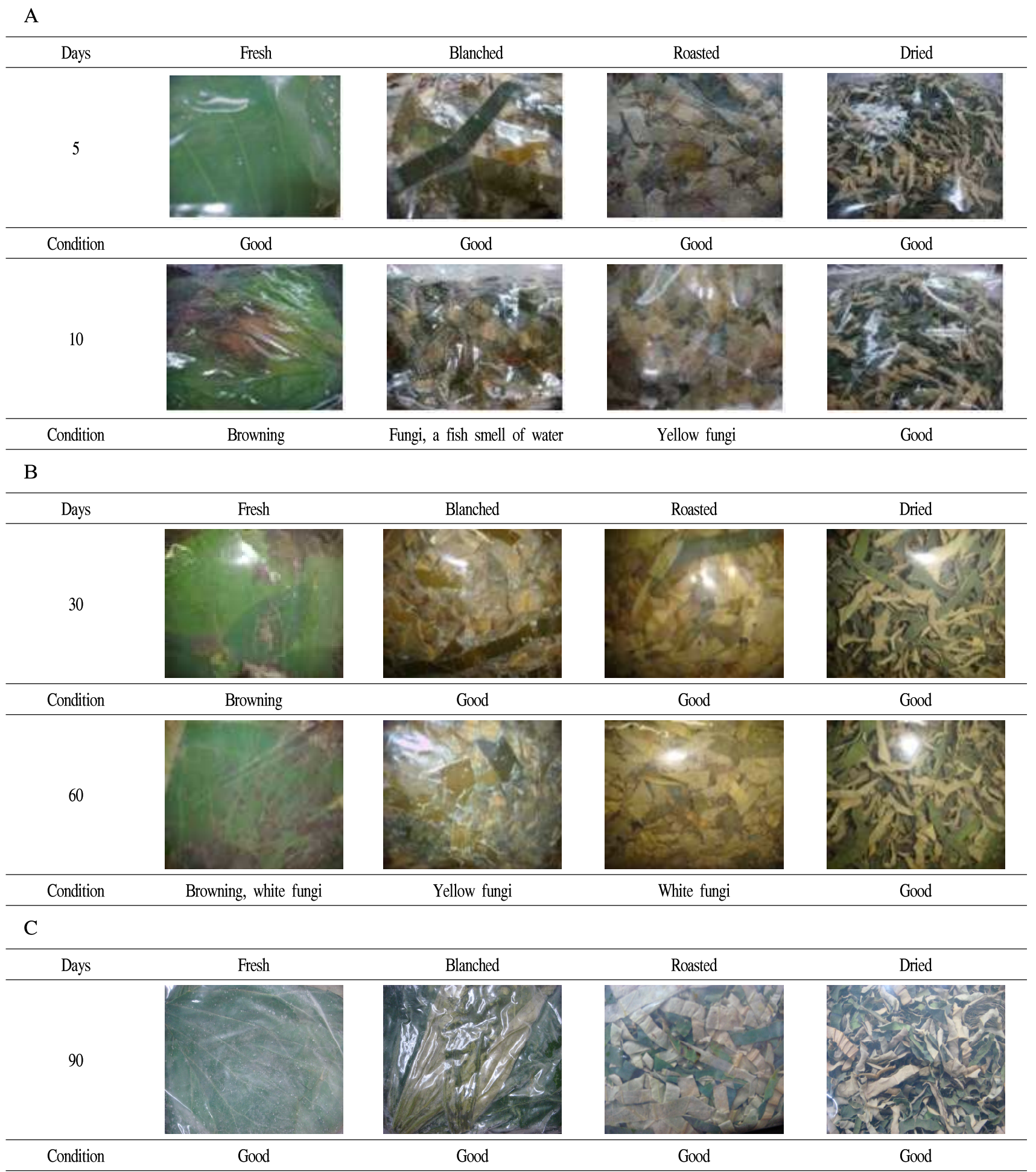

Fig. 1. Appearance of lotus leaves during storage (A, at $25^{\circ} \mathrm{C}$; B, at $4^{\circ} \mathrm{C} ; \mathrm{C},-10^{\circ} \mathrm{C}$ ). 
상관없이 90 일까지는 저장이 가능한 것을 알 수 있었다 (Fig. 1).

\section{$\mathrm{pH}$, 총산 및 가용성 고형분 함량특성}

Table 1 Table 3에서 보는 바와 같이, 저장온도를 달리한 연잎의 전처리별 $\mathrm{pH}$ 는 각 온도별로 조금 다른 양상을 띠고 있었지만 전반적으로 데치기를 한 연잎 처리구의 $\mathrm{pH}$ 가 다 소 높게 나타났고 건조처리를 한 연잎의 $\mathrm{pH}$ 가 낮게 나타났 다. 또한, 총산에서도 전처리별로 유의적인 차이를 보였다 $(\mathrm{p}<0.05)$. 전반적으로 데치기를 한 연잎의 총산이 다소 낮게 나타났고 오히려 건조처리를 한 연잎의 총산이 높게 나타났 다. 연잎의 가용성 고형분 함량은 저장 5 일 $25^{\circ} \mathrm{C}$, 저장 30 일 $4{ }^{\circ} \mathrm{C}$ 및 저장 90 일 $-10^{\circ} \mathrm{C}$ 에서 거의 비슷한 양상을 보였으나
각 온도에서 건조 전처리를 한 연잎에서 큰 차이를 보였다 $(\mathrm{p}<0.05)$. 반면 각 온도에서 데치기 경우, $0.17 \sim 0.23$ 으로 낮 은 수치를 보였다. 이것은 전처리 과정에서 원료의 수분 증발에 의한 수분의 함량 차이에 따른 것이라 추측할 수 있다. Table 4에서 나타낸 바와 같이, $\mathrm{pH}$, 총산 및 가용성 고형분 함량은 각 처리별로 저장온도간에는 유의성을 보이 지 않았다.

\section{총폴리페놀 함량 특성}

식물계에 널리 분포되어 있는 페놀성 화합물은 다양한 구조와 분자량을 가지며 phenolic hydroxyl기가 단백질과 같은 거대분자와 결합하여 항산화, 항암, 항균 등의 생리기 능성을 나타내는 것으로 알려졌다(24-26). 모든 저장온도에

Table 1. Storage properties of lotus leaves with different pretreatments at $25^{\circ} \mathrm{C}$

\begin{tabular}{ccccccc}
\hline Pre-treatments & $\begin{array}{c}\text { Soluble solids } \\
\left({ }^{\circ} \text { Brix }\right)\end{array}$ & $\mathrm{pH}$ & Total acid $(\%, \mathrm{w} / \mathrm{v})$ & $\begin{array}{c}\text { Polyphenol } \\
(\mathrm{mg} / \mathrm{kg} \mathrm{GAE})\end{array}$ & $\begin{array}{c}\text { Bacteria } \\
(\mathrm{CFU} / \mathrm{mL})\end{array}$ & $\begin{array}{c}\text { Molds } \\
(\mathrm{CFU} / \mathrm{mL})\end{array}$ \\
\hline Fresh & $\left.0.37 \pm 0.15^{1 \mathrm{1}) 2}\right)$ & $5.33 \pm 0.09^{\mathrm{b}}$ & $0.03 \pm 0.01^{\mathrm{b}}$ & $381.33 \pm 8.36^{\mathrm{b}}$ & $1.03 \times 10^{5}$ & $\mathrm{ND}^{4)}$ \\
Blanched & $0.23 \pm 0.06^{\mathrm{b}}$ & $5.71 \pm 0.17^{\mathrm{a}}$ & $0.01 \pm 0.00^{\mathrm{d}}$ & $206.73 \pm 3.75^{\mathrm{d}}$ & $32 \times 10^{5}$ & $\mathrm{ND}$ \\
Roasted & $0.33 \pm 0.06^{\mathrm{b}}$ & $5.46 \pm 0.09^{\mathrm{b}}$ & $0.02 \pm 0.00^{\mathrm{c}}$ & $308.12 \pm 2.46^{\mathrm{c}}$ & $0.88 \times 10^{5}$ & $\mathrm{ND}$ \\
Dried & $0.77 \pm 0.06^{\mathrm{a}}$ & $5.23 \pm 0.14^{\mathrm{a}}$ & $0.04 \pm 0.00^{\mathrm{a}}$ & $587.03 \pm 12.98^{\mathrm{a}}$ & $259.7 \times 10^{5}$ & $\mathrm{ND}$ \\
\hline
\end{tabular}

${ }^{1)}$ Each value is mean \pm SD $(n=3)$.

${ }^{2)}$ Means in a column by different superscripts are significantly different at $\mathrm{p}<0.05$ significance level by Duncan's multiple range test.

${ }^{3)} \mathrm{GAE}$, gallic acid equivalent.

${ }^{4)} \mathrm{ND}$, not detected.

Table 2. Storage properties of lotus leaves with different pretreatments at $4^{\circ} \mathrm{C}$

\begin{tabular}{|c|c|c|c|c|c|c|}
\hline Pre-treatments & $\begin{array}{l}\text { Soluble solids } \\
\quad\left({ }^{\circ} \text { Brix }\right)\end{array}$ & $\mathrm{pH}$ & $\begin{array}{l}\text { Total acid } \\
(\%, \mathrm{w} / \mathrm{v})\end{array}$ & $\begin{array}{l}\text { Polyphenol } \\
\left(\mathrm{mg} / \mathrm{kg} \mathrm{GAE}^{3)}\right)\end{array}$ & $\begin{array}{c}\text { Bacteria } \\
(\mathrm{CFU} / \mathrm{mL})\end{array}$ & $\begin{array}{c}\text { Molds } \\
(\mathrm{CFU} / \mathrm{mL})\end{array}$ \\
\hline Fresh & $0.27 \pm 0.06^{1) b 2)}$ & $5.31 \pm 0.01^{c}$ & $0.02 \pm 0.00^{b}$ & $375.14 \pm 2.28^{b}$ & $0.25 \times 10^{5}$ & $\mathrm{ND}^{4)}$ \\
\hline Blanched & $0.17 \pm 0.06^{b}$ & $5.85 \pm 0.26^{\mathrm{a}}$ & $0.01 \pm 0.00^{c}$ & $185.22 \pm 0.73^{\mathrm{d}}$ & $36 \times 10^{5}$ & $\mathrm{ND}$ \\
\hline Roasted & $0.33 \pm 0.12^{b}$ & $5.60 \pm 0.08^{b}$ & $0.02 \pm 0.00^{b}$ & $287.06 \pm 5.49^{c}$ & $42 \times 10^{5}$ & $2.5 \times 10^{3}$ \\
\hline Dried & $0.80 \pm 0.10^{\mathrm{a}}$ & $5.20 \pm 0.04^{\mathrm{c}}$ & $0.04 \pm 0.01^{\mathrm{a}}$ & $738.36 \pm 16.83^{\mathrm{a}}$ & $370 \times 10^{5}$ & $2.5 \times 10^{3}$ \\
\hline
\end{tabular}

${ }^{1)}$ Each value is mean \pm SD ( $\left.n=3\right)$.

${ }^{2)}$ Means in a column by different superscripts are significantly different at $\mathrm{p}<0.05$ significance level by Duncan's multiple range test.

${ }^{3)} \mathrm{GAE}$, gallic acid equivalent.

${ }^{4)} \mathrm{ND}$, means not detected.

Table 3. Storage properties of lotus leaves with different pretreatments at $-10^{\circ} \mathrm{C}$

\begin{tabular}{ccccccc}
\hline Pre-treatments & $\begin{array}{c}\text { Soluble solids } \\
\left({ }^{\circ} \text { Brix }\right)\end{array}$ & $\mathrm{pH}$ & Total acid $(\%, \mathrm{w} / \mathrm{v})$ & $\begin{array}{c}\text { Polyphenol } \\
(\mathrm{mg} / \mathrm{kg} \mathrm{GAE})\end{array}$ & $\begin{array}{c}\text { Bacteria } \\
(\mathrm{CFU} / \mathrm{mL})\end{array}$ & $\begin{array}{c}\text { Molds } \\
(\mathrm{CFU} / \mathrm{mL})\end{array}$ \\
\hline Fresh & $0.37 \pm 0.06^{1) 62)}$ & $5.34 \pm 0.08^{\mathrm{c}}$ & $0.02 \pm 0.01^{\mathrm{b}}$ & $386.80 \pm 100.56^{\mathrm{b}}$ & $0.15 \times 10^{5}$ & $\mathrm{ND}^{4)}$ \\
Blanched & $0.23 \pm 0.06^{\mathrm{c}}$ & $5.79 \pm 0.03^{\mathrm{a}}$ & $0.01 \pm 0.00^{\mathrm{c}}$ & $178.79 \pm 12.65^{\mathrm{c}}$ & $0.04 \times 10^{5}$ & $\mathrm{ND}$ \\
Roasted & $0.37 \pm 0.06^{\mathrm{b}}$ & $5.53 \pm 0.09^{\mathrm{b}}$ & $0.02 \pm 0.00^{\mathrm{b}}$ & $308.74 \pm 26.92^{\mathrm{b}}$ & $0.05 \times 10^{5}$ & $\mathrm{ND}$ \\
Dried & $0.77 \pm 0.06^{\mathrm{a}}$ & $5.10 \pm 0.10^{\mathrm{d}}$ & $0.04 \pm 0.00^{\mathrm{a}}$ & $721.53 \pm 91.66^{\mathrm{a}}$ & $122 \times 10^{5}$ & $7.4 \times 10^{3}$ \\
\hline
\end{tabular}

${ }^{1)}$ Each value is mean \pm SD $(n=3)$.

${ }^{2)}$ Means in a column by different superscripts are significantly different at $\mathrm{p}<0.05$ significance level by Duncan's multiple range test.

${ }^{3)} \mathrm{GAE}$, gallic acid equivalent.

${ }^{4)} \mathrm{ND}$, not detected. 
서 연잎의 폴리페놀 함량을 측정한 결과(Table 1-Table 3), 전처리에 따라 총 폴리페놀 함량이 $185.2 ~ 738.4 \mathrm{mg} / \mathrm{kg} \mathrm{GAE}$ 으로 나타났다. 그 중에서도 건조시킨 처리구가 제일 높게 나왔고 다음으로 생잎 처리구에서 높게 나타났다. 덖음이 나 데치기 처리를 한 연잎 처리구의 경우, 생잎보다 낮은 수치로 나왔다. 덖음처리를 함으로써 연잎의 폴리페놀산화 효소를 불활성시켜 산화를 방지하기 위한 것이었으나(23) 오히려 전처리 과정에서 폴리페놀 성분이 산화된 것으로 판단되고 데치기의 경우는 Jeong 등의(27) 연구에서와 같이 데치기를 함으로써 폴리페놀 물질이 물에 용해되어 소실되 므로 그 값이 감소되었을 것으로 사료된다.

한편, 폴리페놀 함량은 저장온도와 처리구간에 차이가 있음을 보여주었다(Table 4). 전처리별 각 저장온도에 있어 서, 데치기와 건조 처리한 연잎이 저장온도에 따라 폴리페 놀 함량이 유의적인 차이가 있었다. 데치기 처리에서는 2 $5^{\circ} \mathrm{C}$ 에서 저장한 것이 유의적으로 높았고 $(206.73 \mathrm{mg} / \mathrm{kg}$ $\mathrm{GAE})$, 건조 처리한 연잎은 저장온도 $4{ }^{\circ} \mathrm{C}$ 에서 $738.36 \mathrm{mg} / \mathrm{kg}$ $\mathrm{GAE}$ 으로 유의적으로 높았다.

Table 4. Properties of pretreated lotus leaves at different storage temperatures

\begin{tabular}{|c|c|c|c|c|c|}
\hline Pre-treatments & $\begin{array}{l}\text { Storage } \\
\text { temp. } \\
\left({ }^{\circ} \mathrm{C}\right)\end{array}$ & $\begin{array}{l}\text { Soluble solids } \\
\quad\left({ }^{\circ} \text { Brix }\right)\end{array}$ & $\mathrm{pH}$ & $\begin{array}{c}\text { Total acid } \\
(\%, w / v)\end{array}$ & $\begin{array}{l}\text { Polyphenol } \\
\left.(\mathrm{mg} / \mathrm{kg} \mathrm{GAE})^{3}\right)\end{array}$ \\
\hline \multirow{3}{*}{ Fresh } & 25 & $0.37 \pm 0.15^{1)}$ & $5.33 \pm 0.09$ & $0.03 \pm 0.01$ & $381.33 \pm 8.36$ \\
\hline & 4 & $0.27 \pm 0.06$ & $5.31 \pm 0.01$ & $0.03 \pm 0.00$ & $375.14 \pm 2.28$ \\
\hline & -10 & $0.37 \pm 0.06$ & $5.34 \pm 0.08$ & $0.03 \pm 0.01$ & $386.80 \pm 100.56$ \\
\hline \multirow{3}{*}{ Blanched } & 25 & $0.23 \pm 0.06$ & $5.71 \pm 0.17$ & $0.01 \pm 0.00$ & $206.73 \pm 3.75^{22)}$ \\
\hline & 4 & $0.17 \pm 0.06$ & $5.85 \pm 0.26$ & $0.02 \pm 0.00$ & $185.22 \pm 0.73^{\mathrm{b}}$ \\
\hline & -10 & $0.23 \pm 0.06$ & $5.79 \pm 0.03$ & $0.01 \pm 0.00$ & $178.79 \pm 12.65^{b}$ \\
\hline \multirow{3}{*}{ Roasted } & 25 & $0.33 \pm 0.06$ & $5.46 \pm 0.09$ & $0.03 \pm 0.00$ & $308.12 \pm 2.46$ \\
\hline & 4 & $0.33 \pm 0.12$ & $5.60 \pm 0.08$ & $0.03 \pm 0.00$ & $287.06 \pm 5.49$ \\
\hline & -10 & $0.37 \pm 0.06$ & $5.53 \pm 0.09$ & $0.03 \pm 0.00$ & $308.74 \pm 26.92$ \\
\hline \multirow{3}{*}{ Dried } & 25 & $0.77 \pm 0.06$ & $5.23 \pm 0.14$ & $0.07 \pm 0.00$ & $587.03 \pm 12.98^{\mathrm{b}}$ \\
\hline & 4 & $0.80 \pm 0.10$ & $5.31 \pm 0.01$ & $0.06 \pm 0.01$ & $738.36 \pm 16.83^{\mathrm{a}}$ \\
\hline & -10 & $0.77 \pm 0.06$ & $5.10 \pm 0.10$ & $0.07 \pm 0.00$ & $721.53 \pm 91.66^{\mathrm{a}}$ \\
\hline \multicolumn{2}{|c|}{ Significance } & F-value & & & \\
\hline \multicolumn{2}{|c|}{ Storage temp. (S) } & 0.913 & 0.761 & 0.913 & 1.750 \\
\hline \multicolumn{2}{|c|}{ Pretreatments $(\mathrm{P})$} & $120.000^{* 4)}$ & $46.042^{*}$ & $86.783^{*}$ & $240.198^{*}$ \\
\hline \multicolumn{2}{|c|}{$S \times P$} & 0.600 & 0.846 & 0.565 & $3.790^{*}$ \\
\hline
\end{tabular}

${ }^{1)}$ Each value is mean \pm SD $(n=3)$.

${ }^{2)}$ Means in a column by different superscripts are significantly different at $\mathrm{p}<0.05$ significance level by Duncan's multiple range test.

${ }^{3)} \mathrm{GAE}$, gallic acid equivalent.

4) significant at $\mathrm{p}<0.05$.

\section{유기산 함량특성}

연잎에는 주석산(tartaric acid), 구연산(citric acid), 사과 산(malic acid) 및 호박산(succinic acid) 등이 함유되어 있다 $(10,28)$. Yang 등(4)의 연구에서 품종별, 부위별 유기산 함량 을 살펴보면, 잎의 경우 백련이나 홍련이나 모두 malic acid, succinic acid, acetic acid만이 검출되었고 oxalic acid, citric acid, tartaric acid, formic acid 등은 검출되지 않았다. 본 연구에서는 상온 $\left(25^{\circ} \mathrm{C}\right)$ 저장 5 일째, 냉장 $\left(4^{\circ} \mathrm{C}\right)$ 저장 30 일째, 냉동 $\left(-10^{\circ} \mathrm{C}\right)$ 저장 90 일째 연잎 추출액의 유기산을 측정한 결과, 모든 처리구에서 호박산(succinic acid)이 가장 많은 함량을 차지하였다 $(142.5 ~ 908.3 \mathrm{mg} / \mathrm{kg})$. 그 다음으로는 oxalic acid(388.5 0.7 mg/kg), citric $\operatorname{acid}(239.5 \sim 53.5 \mathrm{mg} / \mathrm{kg})$, malic acid(85.4 27.5 mg/kg), tartaric $\operatorname{acid}(64.3 \sim 0 \mathrm{mg} / \mathrm{kg})$ 순 이었다(Table 5). 이중에서 각 온도별 건조 처리한 구에서 $863.5 \sim 908.3 \mathrm{mg} / \mathrm{kg}$ 의 succinic acid 함량을 나타냈는데 이는 연잎에서 유기산 함량을 살펴본 선행 연구의 결과와(4) 비 슷한 결과로 볼 수 있다.

\section{미생물 오염특성}

전처리별로 각 저장온도에서 총균수와 곰팡이수 검사를 한 결과(Table 1-Table 3$)$, 상온 $\left(25^{\circ} \mathrm{C}\right)$ 에서 5 일간 보관한 건 조연잎의 외관과는 달리 건조 처리구에서 세균번식이 많았 다. 냉장 $\left(4^{\circ} \mathrm{C}\right)$ 에서 30 일간 보관한 연잎의 건조 처리구에서 세균번식이 가장 많았고 생잎의 경우 다른 처리구에 비해 세균번식이 현저하게 낮았다. 이는 연잎 추출물의 항균효 과를 살펴본 선행 연구 결과나(11) 연잎을 넣어 절편을 만들 어 저장기간에 따라 총균수의 변화를 살펴본 연구에서와 같이(15) 연잎이 미생물 생육을 억제시킬 수 있다는 것을 볼 수 있었는데 본 연구에서는 전처리하지 않은 생잎에서 항균효과를 내는 성분이 작용한 것으로 추측할 수 있었다. 냉장 $\left(4^{\circ} \mathrm{C}\right)$ 보관 30 일째에서는 덖음과 건조 처리구에서 곰팡 이가 나타났다. 냉동 $\left(-10^{\circ} \mathrm{C}\right)$ 보관 90 일째 연잎 처리구들 중 에서는 건조 처리구에서 세균번식이 현저하게 많았다. 또 한, 냉동 $\left(-10^{\circ} \mathrm{C}\right)$ 보관 90 일째에 건조 처리구에서는 곰팡이가 나타났다. 건조에 의한 수분 함량의 감소에도 불구하고 미 생물의 생육을 볼 수 있다는 것은 좀 더 확인이 필요할 것으로 사료되나 전처리의 영향이라기보다는 저장 중의 오염에 의한 것으로 판단된다.

\section{요 약}

본 실험은 연잎의 전처리방법 및 저장온도에 따른 연잎 의 저장특성을 구명하기 위해 실시되었다. 연잎을 각각 생 잎, 데치기, 덖음 및 건조로 구분하여 처리하고 온도별로 실온 $\left(25^{\circ} \mathrm{C}\right)$, 냉장 $\left(4^{\circ} \mathrm{C}\right)$, 및 냉동 $\left(-10^{\circ} \mathrm{C}\right)$ 에 저장하면서 연 잎의 품질특성을 조사하였다. 외관상으로 실온에서 보관한 연잎 은 저장 5 일까지, 냉장 보관한 연잎은 저장 30 일까지, 냉동 저장한 연잎은 90 일까지 양호하였다. 동일 저장온도 조건 
Table 5. Organic acid contents of pretreated lotus leaves at different storage temperatures

\begin{tabular}{|c|c|c|c|c|c|c|}
\hline \multirow{2}{*}{ Pre-treatments } & \multirow{2}{*}{$\begin{array}{l}\text { Storage temp. } \\
\quad\left({ }^{\circ} \mathrm{C}\right)\end{array}$} & \multicolumn{5}{|c|}{ Organic acids (mg/kg) } \\
\hline & & Oxalic acid & Citric acid & Tartaric acid & Malic acid & Succinic acid \\
\hline \multirow{4}{*}{ Fresh } & 25 & $128.8 \pm 24.6^{1)}$ & $135.2 \pm 22.8$ & $14.2 \pm 8.5$ & $40.4 \pm 12.8$ & $221.1 \pm 20.5$ \\
\hline & 4 & $117.9 \pm 33.3$ & $107.4 \pm 2.6$ & $10.5 \pm 5.6$ & $29.6 \pm 1.9$ & $218.1 \pm 27.8$ \\
\hline & -10 & $107.8 \pm 6.0$ & $144.2 \pm 44.2$ & $22.2 \pm 19.2$ & $44.5 \pm 12.7$ & $220.0 \pm 9.5$ \\
\hline & F-value & 0.563 & 1.333 & 0.680 & 1.627 & 0.017 \\
\hline \multirow{4}{*}{ Blanched } & 25 & $87.5 \pm 12.8^{92)}$ & $66.1 \pm 7.8$ & $16.5 \pm 7.5^{\mathrm{a}}$ & $28.7 \pm 2.1$ & $174.9 \pm 30.7$ \\
\hline & 4 & $57.9 \pm 3.9^{\mathrm{b}}$ & $63.6 \pm 4.0$ & $13.1 \pm 6.3^{\mathrm{a}}$ & $27.5 \pm 3.2$ & $156.1 \pm 26.4$ \\
\hline & -10 & $58.3 \pm 10.2^{\mathrm{b}}$ & $53.5 \pm 2.8$ & $0 \pm 0^{\mathrm{b}}$ & $27.8 \pm 3.4$ & $142.5 \pm 1.9$ \\
\hline & F-value & $9.134^{* 3)}$ & 4.750 & $7.213^{*}$ & 0.141 & 1.457 \\
\hline \multirow{4}{*}{ Roasted } & 25 & $150.5 \pm 26.3$ & $104.1 \pm 20.4$ & $13.0 \pm 5.5$ & $40.5 \pm 5.4$ & $256.4 \pm 60.9$ \\
\hline & 4 & $151.7 \pm 30.9$ & $129.4 \pm 20.9$ & $8.8 \pm 1.1$ & $38.6 \pm 5.6$ & $293.2 \pm 40.9$ \\
\hline & -10 & $147.3 \pm 11.2$ & $107.0 \pm 17.4$ & $7.6 \pm 0.2$ & $36.8 \pm 4.9$ & $305.6 \pm 2.6$ \\
\hline & F-value & 0.026 & 1.485 & 2.361 & 0.358 & 1.093 \\
\hline \multirow{4}{*}{ Dried } & 25 & $388.5 \pm 23.6^{\mathrm{a}}$ & $182.0 \pm 35.2$ & $36.6 \pm 16.9$ & $69.1 \pm 16.5$ & $863.5 \pm 50.9$ \\
\hline & 4 & $385.4 \pm 26.4^{\mathrm{a}}$ & $193.5 \pm 67.4$ & $48.7 \pm 26.6$ & $75.4 \pm 23.5$ & $888.8 \pm 131.5$ \\
\hline & -10 & $0.7 \pm 0.3^{\mathrm{b}}$ & $239.5 \pm 43.9$ & $64.3 \pm 35.2$ & $85.4 \pm 9.0$ & $908.3 \pm 97.4$ \\
\hline & F-value & $357.759^{* * * 4)}$ & 1.079 & 0.781 & 0.670 & 0.155 \\
\hline
\end{tabular}

${ }^{1)}$ Each value is mean $\pm \mathrm{SD}(\mathrm{n}=3)$.

${ }^{2)}$ Means in a column by different superscripts are significantly different at $\mathrm{p}<0.05$ significance level by Duncan's multiple range test

${ }^{3)}$ significant at $\mathrm{p}<0.05$.

4) significant at $\mathrm{p}<0.001$

에서 $\mathrm{pH}$, 가용성 고형분 함량, 총산, 폴리페놀 및 미생물 수는 처리간 유의적인 차이를 보였으나 동일 처리조건에서 가용성 고형분함량, $\mathrm{pH}$, 총산 함량이 저장온도간에 유의적 인 차이를 보이지 않았다. 다만, 연잎의 폴리페놀 함량과 유기산중 oxalic acid, tartaric acid 함량은 데치기와 건조 처리구에서 저장온도간 유의적인 차이를 보였다. 이러한 결과는 다변량분산분석에서도 나타났는데, 모든 품질 특성 에서 각 온도별 처리구간에는 유의적인 차이를 보인 반면 각 처리구별 저장 온도에는 유의적인 차이를 보이지 않았 다. 특히, 폴리페놀 함량의 경우에는 저장 전 연잎의 처리방 법과 저장온도에 크게 영향을 받는 것으로 나타났다. 결론 적으로, 연잎의 전처리 방법에는 큰 상관이 없이 저장온도 에 크게 영향을 받아 상온에서 5 일, 냉장에서 30 일, 냉동에 서 90 일 정도 상태가 양호한 것으로 나타났다.

\section{감사의 글}

본 연구는 국립농업과학원 농업과학기술연구개발사업 (과제번호: PJ010074)의 지원에 의해 이루어진 것이며, 연 구비 지원에 감사드립니다.

\section{References}

1. Lee KS, Kwon YJ, Lee KY (2008) Analysis of chemical composition, vitamin, mineral and antioxidative effect of the lotus leaf. J Korean Soc Food Sci Nutr, 37, 1622-1626

2. Lee HK, Choi YM, Noh DO, Suh HJ (2005) Antioxidant effect of Korean traditional lotus liquor. Int J Food Sci Technol, 40, 709-715

3. Kim OS, Choi OJ, Shim KH (2012) Effect of pretreatment on the physicochemical properties of lotus root powder. Korean J Food Preserv, 19, 74-80

4. Yang HC, Heo NC, Choi KC, Ahn YJ (2007) Nutritional composition of white-flowered and pink-flowered lotus in different parts. Korean J Food Sci Technol, 39, 14-19

5. Park BH, Kim SD, Jeon ER, Cho HS (2012) Quality characteristics and volatile flavor components of cooked rice, Yenipsambab, with lotus leaf powder. J Korean Soc Food Cult, 27, 374-382

6. Lee KS, Kim MG, Lee KY (2006) Antioxidative activity of ethanol extract from lotus (Nelumbo nucifera) leaf. J Korean Soc Food Sci Nutr, 35, 182-186

7. Jeong IC, Park HS, Choi YJ, Park SS, Kim MJ, Park 
KS (2011) The effects of adding lotus root and leaf powder on the quality characteristics of cooked pork patties. Korean J Food Cook Sci, 27, 783-791

8. Nam KH, Jang MS, Lee DS, Yoon HD, Park HY (2011) Effect of green tea and lotus leaf boiled water extracts treatment on quality characteristics in salted mackerel during storage. Korean J Food Preserv, 18, 643-650

9. Lee KS, Lee KY (2011) Effect of lotus (Nelumbo nucifera) leaf extract on serum and liver lipid levels of rats fed a high fat diet. J Korean Soc Food Sci Nutr, 40, 1544-1547

10. Shin MK, Han SH (2006) Effect of lotus (Nelumbo nucifera Gaertner) leaf powder on lipid concentrations in rats fed high fat diet rats. J Korean Soc Food Cult, 21, 202-208

11. Lee KS, Oh CS, Lee KY (2006) Antimicrobial Effect of the fractions extracted from a lotus (Nelumbo nucifera) leaf. J Korean Soc Food Sci Nutr, 35, 219-223

12. Kim DC, Kim DW, In MJ (2006) Preparation of lotus leaves tea and its quality characteristics. J Korean Soc Food Sci Nutr, 35, 219-223

13. Kim JS, Wang SB, Kang SK, Cho YS, Park SK (2009) Quality properties of white lotus leaf fermented by mycelial Paecilomyces japonica. J Korean Soc Food Sci Nutr, 38, 594-600

14. Park BH, Jeon ER, Kim SD, Cho HS (2010) Quality characteristics of dried noodle added with lotus leaf powder. J Korean Soc Food Cult, 25, 225-231

15. Han KY, Yoon SJ (2007) Quality characteristics of lotus leaf Jeolpyun during storage. J Korean Soc Food Sci Nutr, 36, 1604-1611

16. Park BH, Cho HS, Jeon ER, Kim SD (2009) Quality characteristics of Jook prepared with lotus leaf powder. Korean J Food Cook Sci, 25, 55-61

17. Park SH, Chang KH, Byun GI, Kang WW (2009) Quality characteristics of bread made with flour partly substituted by lotus leaf powder. Korean J Food Preserv, 16, 47-52

18. Jeong CS, Um GJ, Park JN (2010) Changes of storage temperatures on the physiological characteristics in leafy vegetables. J Agric Life Sci, 22, 33-41
19. Choi HD, Koh YJ, Kim YS, Choi IW, Cha DS (2007) Changes in physicochemical and sensory characteristics of dandelion (Taraxacum officinale) leaves by roasting treatment. Korean J Food Sci Technol, 39, 515-520

20. Lee YJ, Lee HO, Kim JY, Kwon KH, Cha HS, Kim BS (2011) Quality characteristics of frozen Doraji (Platycodon grandiflorum) according to various blanching treatment conditions. Korean J Food Preserv, 18, 661-668

21. Lee BS, Lee WY (2010) Changes in the chemical composition of apple slices pretreated with supercritical carbon dioxide. Korean J Food Preserv, 17, 256-260

22. Jung SM, Chang EH, Park SJ, Jeong ST, Roh JH, Hur YY, Lee HC (2010) Berry thinning effects on the fruit and wine quality of grape 'Muscat Bailey A'. Korean J Food Preserv, 17, 625-630

23. Kong MH, Yeo SH, Choi JH, Choi HS, Jeong ST (2011) Characteristics of the Yakju fermented with differentlyprocessed lotus leaves. J East Asian Soc Dietary Life, 21, 911-917

24. Woo KS, Song SB, Oh BG, Seo MC, Ko JY, Lee JS, Kang JR, Nam MH, Jeong HS (2009) Antioxidant activity of ethanol extracts from Horseweed (Erigeron canadensis L.) with pretreatment conditions. J Korean Soc Food Sci Nutr, 38, 1279-1283

25. Choi YM, Kim MH, Shin JJ, Park JM, Lee JS (2003) The antioxidant activities of the some commercial teas. J Korean Soc Food Sci Nutr, 32, 723-727

26. Jeong CH, Son KB, Kim JH, Kang SK, Park EY, Seo KI, Shim KH (2010) Antioxidant and anticancer activities of lotus (Nelumbo nucifera) leaf and root. Korean J Food Preserv, 17, 131-138

27. Jeong JS, Kim YJ, Choi BR, Go GB, Son BG, Gang SW, Moon SM (2014) Antioxidant and physicochemical changes in Salvia plebeia R. Br. after hot-air drying and blanching. J Korean Soc Food Sci Nutr, 43, 893-900

28. Kim HS, Lee CH, Oh JW, Lee JH, Lee SK (2011) Quality characteristics of sponge cake with added lotus leaf and lotus root powders. J Korean Soc Food Sci Nutr, 40, 1285-1291 